\title{
Foreign market selection process as tool for international expansion: Case study for ecuadorian chia seeds exports to the european union
}

\author{
EDUARDO TERÁN-YÉPEZ, LUNA SANTOS-ROLDÁN, \\ BEATRIZ PALACIOS-FLORENCIO \& JUAN MANUEL BERBEL-PINEDA
}

\begin{abstract}
To assist Ecuadorian chia seed producers in their quest for internationalisation. This article uses a case study to present a methodology which assists in the selection of the most suitable export market for a product. It is based on a diverse range of indicators grouped into 7 dimensions that were used to analyse the 27 member countries of the European Union in order to determine the most suitable export market for chia seeds from Ecuador. Germany is the biggest European importer of chia seeds with a 55\% share, followed by the Netherlands, the United Kingdom and Spain. It presents a methodology for market selection that can be employed as a tool for international expansion which can easily be used by companies in search of the most suitable export market for their products.
\end{abstract}

Key words: chia seeds, Ecuador, international market selection, Internationalisation, European Union.

\section{INTRODUCTION}

Nowadays, commercial activities are carried out in a context that is increasingly globalised and characterised by a decreasing number of import barriers, growing levels of competition and a rise in the number of opportunities for international expansion (Morton 1995, Górecka \& Szałucka 2013). A company must, however, make several strategic decisions before initiating its international expansion, one of which is the selection of the most suitable market (Hingley et al. 2009, Terán-Yépez \& Santos-Roldán 2018). Identifying international markets with preferable conditions is vital for the success of a company, as mistakes made during this stage of the process can be very costly (Viviers et al. 2014).
A wide range of macroeconomic, sociopolitical, purchasing power, public services and demand-related factors, trade indicators, as well as cultural and fiscal aspects must be taken into account when choosing a market for international expansion (Berbel-Pineda et al. 2012). The objective of this paper is to present a methodology for export market selection as a tool for international expansion, which can easily be used by companies when faced with the task of choosing the most suitable market for the internationalisation of a product. This paper illustrates the usefulness of the method by presenting a case study describing the selection of the most suitable EU market for the export of Ecuadorian chia seeds. The scope of this paper is limited to a selection analysis based on company-external factors represented 
by a combination of indicators grouped into 7 dimensions.

The article consists of an introduction, six sections and a conclusion. The first section describes the characteristics and relevance of chia seeds as a product. The second briefly summarises the significant role the agricultural sector plays in Ecuador's economy and explains the current reality of the chia seed business in the country. The third section presents a variety of scientific contributions focused on the process of market selection for internationalisation. Sections four and five describe the methodology employed to select the most suitable market, and the case study illustrating the selection of the most suitable EU export market for Ecuadorian chia seeds. Lastly, section six shows the results obtained through the application of the method.

\section{LITERATURE REVIEW}

\section{Chia seeds}

Salvia hispánica L., commonly known as chia is an ancestral oil seed originating in Mesoamerica, specifically the mountain regions in the central and southern regions of Mexico, Nicaragua and Guatemala, used by the Mayas and Aztecs as a food source (Ramírez-Jaramillo \& LozanoContreras 2015, Cahill 2004). It is a natural source of Omega-3 fatty acids, soluble and insoluble fibres as well as proteins and other important nutritional components such as vitamins, minerals and natural antioxidants (Muñoz et al. 2013).

In 2009, the European Food Safety Authority declared whole and ground chia seeds to be safe food ingredients (European Food Safety Authority 2009). Additionally, research carried out by the United States Food and Drug Administration in 2013 on the negative effects of trans fatty acids, saturated fats and the growing imbalance of Omega- 3 and 6 fatty acids in Western diets, as well as the benefits associated with the consumption of Omega-3 fatty acids in the fight against certain cardiovascular diseases, cancer, depression and other pathologies, led to growing expectations for the cultivation of chia seeds, which in turn, led to increased consumption beyond the borders of Mexico and triggered its geographical expansion (Ayerza \& Coates 2005, United States Food and Drug Administration 2013).

Chia is considered a "superfood" by the United States Food and Drugs Administration (FDA), and has been since 2013, owing to its high Omega-3 and fibre content and the fact that it is not only a simple food source but also increases levels of satiety, prevents cardiovascular diseases, inflammatory and nervous disorders as well as diabetes, as it contains "twice as much potassium as a banana, twice as much fibre as any cereal flakes, three times as much iron as spinach, eight times as much Omega 3 as an Atlantic salmon, nine times as much phosphate as whole milk, six times as much assimilable calcium as whole milk and fifteen times as much magnesium as broccoli, to name some of the benefits". Nowadays, thanks to their functional components, chia seeds offer enormous potential for the health, food, animal feed, pharmaceutical and other sectors (Muñoz et al. 2013, United States Food and Drug Administration 2013).

As for the international chia seed market, it must be mentioned that chia seeds do not have their own tariff subheading and are classified under subheading 1207.99, which also contains a variety of other seeds. Consequently, some of

\footnotetext{
1 According to the Food and Drugs Administration, to be considered a superfood, a food must meet three requirements: first, it needs to be an excellent source of fibre, vitamins and minerals; second, it must have a high content of phytonutrient and antioxidant compounds such as vitamin A, E and betacarotene; third, it has to be characterised by low caloric density.
} 
the statistics provided in this article reflect the values calculated for all of them.

In Table I and Figure 1, we can observe the evolution of global imports as well as imports by the European Union (in volume) and the share of those as part of global imports under tariff subheading 1207.99 for the years 2001-2016. As can be observed, from 2001 to 2016 global imports under said subheading have increased by $229 \%$, while the volume imported by the $\mathrm{EU}$ has increased by $255 \%$ for the same time period. It is worth noting that world imports suffered a slump in 2016, when compared to 2014 and 2015, while imports by the EU in 2016 were greater than those registered in the two previous years. It is equally noteworthy that EU imports as a share of total global imports falling under the mentioned tariff subheading for the year 2016 were $38 \%$, which represents the highest value for the time period in question.

According to data released by the Dutch Ministry of Foreign Trade, the EU imported approximately 11,838 metric tonnes of chia seeds in the year 2015, which represents an increase in volume of $300 \%$ when compared to 2012 , when approximately 3,485 metric tonnes of Salvia hispánica L. were imported. Moreover, according to Grand View Research (2016) the consumption in the EU of products containing Omega-3 will increase at an annual rate of $13.7 \%$ in the period between 2017 and 2022. These data allow for the conclusion that chia seed imports by the EU will continue to rise and that global supply will need to increase (Netherlands Ministry of Foreign Affairs 2016).

Table I. Global imports, EU imports and value of EU imports as share of global imports under tariff subheading 1207.99 between 2001 and 2016 (in metric tonnes).

\begin{tabular}{|c|c|c|c|}
\hline Years & World & $\begin{array}{l}\text { European Union without United } \\
\text { Kingdom (EU27) }\end{array}$ & $\%$ of global imports represented by EU imports \\
\hline 2001 & 194,670 & 65,581 & $34 \%$ \\
\hline 2002 & 268,427 & 99,499 & $37 \%$ \\
\hline 2003 & 251,792 & 94,796 & $38 \%$ \\
\hline 2004 & 410,882 & 69,370 & $17 \%$ \\
\hline 2005 & 336,552 & 100,346 & $30 \%$ \\
\hline 2006 & 309,826 & 92,752 & $30 \%$ \\
\hline 2007 & 496,854 & 119,783 & $24 \%$ \\
\hline 2008 & 559,018 & 126,906 & $23 \%$ \\
\hline 2009 & 568,529 & 135,669 & $24 \%$ \\
\hline 2010 & 575,298 & 140,134 & $24 \%$ \\
\hline 2011 & 504,636 & 144,066 & $29 \%$ \\
\hline 2012 & 406,345 & 119,361 & $29 \%$ \\
\hline 2013 & 438,428 & 123,710 & $28 \%$ \\
\hline 2014 & 542,937 & 138,616 & $26 \%$ \\
\hline 2015 & 497,058 & 161,975 & $33 \%$ \\
\hline 2016 & 446,069 & 167,416 & $38 \%$ \\
\hline
\end{tabular}

Source: Own elaboration using data obtained from Trade Map (2017). 


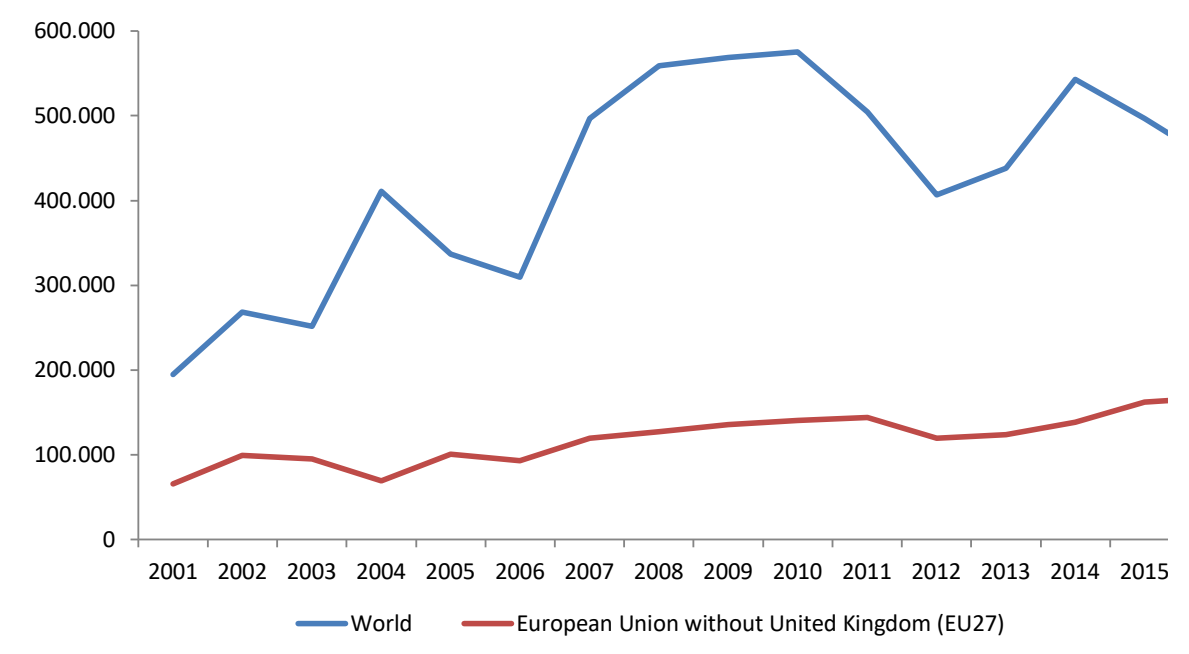
Figure 1. Evolution of global and EU imports under tariff subheading 1207.99 for the years 2001 to 2016 (in metric tonnes). Source: Own elaboration using data obtained from Trade Map (2017).

\section{Agricultural sector in Ecuador and chia seeds}

Throughout its history as a republic, Ecuador has maintained an economic model oriented towards the export of primary goods, and the agricultural sector has always played a major role (Terán, unpublished data). Taking the year 2014 as a starting point, of Ecuadorian non-oil exports 39\% were agricultural. For the year 2015 that figure rose to $44 \%$, and for 2016 to $45 \%$, as can be seen in Table II (Instituto de Promoción de Exportaciones e Inversiones [PROECUADOR] 2017).

Currently, the Ecuadorian agricultural sector enjoys a positive reputation internationally (Camino-Mogro et al. 2016). This is why it is imperative to develop new proposals, respond to the enormous need for reform and restructure the sector's export model by diversifying its productive matrix and adding non-traditional products (Caria, unpublished data) such as chia seeds. However, the cultivation of this seed in Ecuador is a relatively recent activity, and despite a constant evolution in the area of production, companies producing chia seeds still have little experience in international expansion. Moreover, Ecuadorian farmers and entrepreneurs have not been oriented adequately regarding the international prospects of chia seeds, which is why Ecuadorian exports of the seed are generally not yet at an optimal level, neither in the number of countries they reach nor in traded volume (León \& Ochoa, unpublished data).

According to the 2016 report "Exporting chia seeds to Europe" by the Dutch Ministry of Foreign Affairs, Ecuadorian imports represent a mere $0.5 \%$ of the total imports into the European Union for the year 2015, i.e. approximately 60 metric tonnes (Netherlands Ministry of Foreign Affairs 2016). Conversely, the multiparty trade agreement between Ecuador and the European Union signed in November 2016 and taking effect as of 1 January 2017, opens a multitude of export destinations for chia seeds among the member countries of the EU, and, according to the European Commission, Ecuadorian agricultural exports to the EU are expected to increase by $30 \%$. In addition, according to the tariff elimination schedule of the European Union party for goods originating in Ecuador, the tariff subheading corresponding to chia seeds, oil seeds and oleaginous fruits, whether broken or not broken, i.e. 1207.99, is classified as category 0 , which means that as soon as the agreement takes effect, import duties will be $0 \%$ (European Commission 2016). 
Table II. Evolution of Ecuadorian agricultural exports compared with Ecuadorian non-oil exports between 2014 and 2016 (as percentage of FOB value).

\begin{tabular}{|c|c|c|c|}
\hline Year & $\begin{array}{c}\text { Non-oil exports (in thousands of } \\
\text { dollars FOB) }\end{array}$ & $\begin{array}{c}\text { Agricultural exports } \\
\text { (in thousands of dollars FOB) }\end{array}$ & $\begin{array}{c}\text { Agricultural exports as } \\
\text { percentage of non-oil exports }\end{array}$ \\
\hline 2014 & $12,448,569$ & $4,905,964$ & $39 \%$ \\
\hline 2015 & $11,670,175$ & $5,131,540$ & $44 \%$ \\
\hline 2016 & $11,338,465$ & $5,067,200$ & $45 \%$ \\
\hline
\end{tabular}

Source: Own elaboration using data obtained from PROECUADOR (2017).

\section{Market selection process for international expansion}

Literature on the process of market selection is wide-ranging and, over time, many different theories have been put forth defining the stages in the process, the methodologies to be employed in such an undertaking and the indicators to be used to assess an international market (Colantone \& Sleuwaegen 2010). As for the stages of market selection, a number of authors coincide in the description of three: (1) market pre-selection, (2) in-depth research of pre-selected markets and (3) selection of most suitable market (Sakara et al. 2007).

In the pre-selection stage, desk-based research is carried out, mainly using information from secondary sources in order to identify potential markets as candidates for further, more in-depth analyses (Berbel-Pineda et al. 2012). Macro-level indicators are used during this phase in order to discard those markets that are not relevant for a specific export product. During the in-depth research stage, when preselected markets are analysed in more detail, industry attractiveness is evaluated and the market environment of each country is assessed through primary or secondary data, which have been gathered in order to accumulate the largest possible amount of factors that might help in the selection of a target market from the list of pre-selected markets. Finally, during the target market selection stage, the most suitable export market for a product is determined based on the information collected during the first two stages (Górecka \& Szałucka 2013, Marchi et al. 2009).

As far as methodology is concerned, different authors agree that it is necessary to establish a systematic selection process which allows for the creation of a ranking of countries considered possible target markets, in order to prevent business owners from being overly rigorous in the selection process and from letting themselves be guided by prejudice and mere assumptions. Literature also concurs that a methodology for market selection must follow 5 steps: (1) design adequate indicators, (2) collect data and convert them into comparable indicators, (3) establish the appropriate weighting for each indicator, (4) analyse data and (5) select the most suitable market from the market ranking (Hisrich 2015, Górecka \& Szałucka 2013, Marchi et al. 2009).

When it comes to the first step, it is necessary to establish different types of indicators such as: market size indicators (population size, per-capita income, market for the specified product, unemployment rate, population density, etc); market growth indicators (gross domestic product, economic growth, inflation, salaries, etc.), relevant product-specific indicators (number of potential customers, product-specific trade indicators, demand, etc.), indicators such as political and commercial risk, commercial indicators for the target country 
(demand for imports and growth of imports over the previous years), indicators for geographical distance, language barriers and international trade agreements (Hisrich 2015, Viviers et al. 2014, Sheng \& Mullen 2011).

It is also interesting to mention at this point that literature indicates that company strategies (e.g. to target a niche market) and the use of a company's non-economic resources (e.g. brand image, specific asset portfolio) can help lower entry barriers (Michelle \& Byoungho 2014). Companies must also apply a first filter at this point, making a choice between sequential (choosing a target market that is similar to the country of origin) or non-sequential (choosing a target market that is dissimilar to the country of origin) internationalisation for their first attempts at expanding into foreign markets. This can be achieved by applying a filter which rules out countries that have not signed a trade agreement with the country of origin, leaving only those that have, or one that can filter out countries depending on their geographical location, allowing only countries from specific regions like, for example, EU countries, South American countries, etc. for the purpose of the study. This will make it possible to discard a certain number of countries and leave a more manageable quantity to work with (Cuervo-Cazurra 2011).

The second step is to collect data for each one of the indicators established in step one and to convert them into comparable values. During this step, all primary (original information collected for a specific purpose) and secondary data (existing data that has already been published) must be gathered. Usually, secondary data are collected first in order to establish which information still needs to be compiled through primary research. There are certain problems associated with the collection of international secondary data, which might vary in certain ways from country to country, depending on its stage of economic development (Hisrich 2015, Marchi et al. 2009).

Said problems can be divided into four categories: (1) comparability; data from one country might not be the same as those from another as they might be expressed in a different manner; (2); availability; some countries have a lot more data available than others. This is generally a reflection of the stage of economic development of a country; (3) accuracy; sometimes data are collected without applying strict standards or have been distorted in order to promote a specific government agenda; (4) cost; certain countries enjoy freedom of information, which means that all data not related to security or defence are available to all. This kind of transparency, however, does not exist in all countries (Hisrich 2015, Marchi et al. 2009).

Once all data have been compiled, they must be converted to a harmonised standard so that all indicators from every country can be numerically compared with each other. Different methods can be used to achieve this, and each one requires a certain level of perspicacity on the part of the business owner or researcher (Hisrich 2015, Viviers et al. 2014).

The third step requires appropriate weighting to be established for the indicators, reflecting the importance and ability of each one of them to predict the market potential for the export product in question. Taking the example of a school desk manufacturer, the number and types of schools, the age and size of the school buildings, public expenditure in education, as well as the number of students are, among others, all relevant indicators. By assigning a specific weighting to each one, their relative importance in the process can be expressed. Assigning specific weightings and selecting certain indicators varies from one product to another and is, in fact, a somewhat arbitrary process (Hisrich 2015). 
The fourth step is the actual analysis of the results. When looking at the data, results must be examined carefully and called into question. Moreover, a search for possible errors must be carried out and, if found, corrections need to be made. Finally, during the fifth and final step, the target market must first be selected by comparing the various indicators and then monitored in order to define an appropriate entry strategy and market plan (Hisrich 2015, Michelle \& Byoungho 2014).

\section{MATERIALS AND METHODS}

The methodology for international market research and selection presented hereafter is divided into three stages, as illustrated in Table III.
In the first stage, the pre-selection of markets is carried out using mostly information obtained from secondary sources, making use of a variety of institutions as well as public and private entities which provide information relating to foreign markets. During this stage, trade indicators must be collected that are pertinent to the tariff subheading which corresponds to the export product in question in the countries under study, as well as to their relationship with the world. Moreover, indicators must be taken into account which show the relationship between the country of origin and each of the countries under consideration, as well as the country risk represented by each of them. Table IV shows the different indicators to be evaluated in each of the criteria of the first stage.

Table III. Stages and indicators of the market selection methodology.

\begin{tabular}{|c|c|}
\hline Stage & Indicators \\
\hline Market pre-selection & $\begin{array}{l}\text { Trade indicators for the export tariff subheading for the countries under study and their } \\
\text { relationship with the world } \\
\text { Indicators relating to the relationship between the country of origin and the countries } \\
\text { under study } \\
\text { Country risk }\end{array}$ \\
\hline In-depth research & $\begin{array}{l}\text { Physical/demographic environment } \\
\text { Political-economic environment } \\
\text { Legal environment } \\
\text { Socio-cultural environment } \\
\text { Market analysis } \\
\text { Demand for product under study } \\
\text { Entry barriers }\end{array}$ \\
\hline $\begin{array}{l}\text { Market selection } \\
\text { (7 dimensions) }\end{array}$ & $\begin{array}{c}\text { Macroeconomic and political data } \\
\text { Purchasing power } \\
\text { Commercial indicators } \\
\text { Trade relationship between country of origin and target countries } \\
\text { Cultural environment and consumption structure } \\
\text { Legal and fiscal considerations } \\
\text { Public services }\end{array}$ \\
\hline
\end{tabular}

Source: Own elaboration. 
Table IV. Criteria and indicators used in the model during the pre-selection stage.

\begin{tabular}{|c|c|}
\hline Criteria & Indicators \\
\hline $\begin{array}{l}\text { Commercial indicators for the export tariff } \\
\text { subheading for the countries under study, and } \\
\text { their relationship with the world }\end{array}$ & $\begin{array}{c}\text { Value of imports for the last full year } \\
\text { Volume of imports for the last full year } \\
\text { Unit value } \\
\text { Annual growth rate in value over the previous } 5 \text { years (\%) } \\
\text { Annual growth rate in volume over the previous } 5 \text { years (\%) } \\
\text { Annual growth rate in value over the previous year (\%) } \\
\text { Share in world imports } \\
\text { Concentration of supplier countries }\end{array}$ \\
\hline $\begin{array}{l}\text { Indicators for the trade relationship between } \\
\text { country of origin and countries under study }\end{array}$ & $\begin{array}{l}\text { Total value of exports from country of origin for the previous } \\
\text { year } \\
\text { Annual growth rate in value over the previous five years for } \\
\text { exports from the country of origin to the countries under study } \\
\text { Annual growth rate in value over the previous year for exports } \\
\text { from the country of origin to the countries under study }\end{array}$ \\
\hline Country risk & Country risk \\
\hline
\end{tabular}

Source: Own elaboration.

As can be seen in Table IV, as far as trade indicators for the tariff subheading in question for the countries under study are concerned, indicators such as import value, import volume, unit value, growth rates in value and volume, share in world imports and concentration of supplier countries must be taken into account. As for the indicators relating to the trade relationship between the country of origin and the countries under study, the following indicators must be evaluated: export value, growth rate in value over the previous five years as well as growth rate in value for the previous year. Finally, in this stage country risk must also be assessed.

In order to add to the information shown in Table III, during the second stage an in-depth analysis must be carried out of those markets that have been pre-selected in order to obtain data pertaining to areas such as physical/ demographic, politico-economic, legal and cultural environment, market characteristics, product demand and entry barriers. In terms of physical/demographic environment the following data must be collected: population size, size of economically active population, population density, average age, surface area, etc. In terms of politico-economic environment, collected data must include indicators such as GDP, GDP per capita, political risk, commercial risk, economic growth, inflation, salaries, etc.

When it comes to the legal environment it is important to take into account legal as well as fiscal indicators such as general value-added tax, value-added tax for the export product in question, duration of copyright protection for intellectual property, etc. In terms of cultural environment the following indicators are essential: languages, cultural barriers when it comes to the product in question, etc. In the area of market analysis, data must be collected pertaining to economic performance (GDP PPP, GDP PPP per capita, trade balance, etc.), market potential (total imports of the product 
in question) and bilateral trade between the country of origin and the target country (total imports, total exports, trade balance, main import and export products).

In addition, data must be collected showing the potential demand for the product. This could include the number of consumers in the sector, per capita demand, production and share in local consumption as well as number of and distance from competitor countries. In order to complete this stage, data must be gathered concerning entry barriers, be they cultural, tariff or non-tariff related.

Finally, in the third stage, as can be observed in Table III, the target market must be selected by comparing the different indicators collected in stage one and two, evaluating them through a 7-dimensional weighted decision matrix, examining macroeconomic and political criteria, purchasing power, trade indicators, data regarding the commercial relationship between the country of origin and each of the countries under study, cultural and consumer environment, legal and fiscal considerations, as well as public services. Each criterion must be subdivided into a number of analitico-quantitative subcriteria.

Table $V$ shows the 7 dimensions used in this model as well as the different indicators that are grouped into each one of them for the market selection phase.

In each of the 7 dimensions, the different indicators used in this methodology can be observed. They will, however, not be explained in detail as the validity of the method itself and the applicability of the various indicators used will be demonstrated with the help of a case study, in which the method is applied in an attempt to determine the most suitable EU target market for the export of Ecuadorian chia seeds.

\section{CASE STUDY: SELECTION OF THE MOST SUITABLE EU COUNTRY FOR THE EXPORT OF ECUADORIAN CHIA SEEDS}

\section{Market pre-selection}

The multiparty trade agreement with the European Union represents a major opportunity for Ecuadorian chia seed exporters, which is why this case study has omitted non-EU countries and made a pre-selection of 3 of the $27 \mathrm{EU}$ member countries. It is worth remembering that thanks to this agreement Ecuadorian chia seeds are charged $0 \%$ import tariff upon entry into the EU. It is also important to keep in mind that no distinct tariff subheading for chia seeds exists. Subheading 1207.99 includes a variety of seeds, which means that statistics provided in this case study reflect values for all of them.

For the market pre-selection, certain trade indicators related to the tariff subheading 1207.99 as well as to the $27 \mathrm{EU}$ member countries and their relationship with the world were taken into account. They included, among others, value of world imports for the year 2016, volume of world imports for the year 2016, unit value, and growth rate. Furthermore, indicators relating to the commercial relationship between Ecuador and each of the EU member countries were taken into account. In this case, the relationship is not restricted to the tariff subheading 1207.99 but includes exports for all subheadings made from Ecuador to each of the target markets. The risk corresponding to each EU member state is also shown. All of these indicators have been converted to Base 10, using maximum values for each indicator in order to obtain a unified scale. This process can be observed in Table VI.

The country risk used in Table VI was obtained from the Compagnie Française d'Assurance pour le Commerce Extérieur (COFACE), which provide an estimate of the average credit risk on a country and uses the following scale: A1 very 
Table V. 7 dimensions and indicators used in the model during the market selection phase.

\begin{tabular}{|c|c|}
\hline 7 DIMENSIONS & INDICATORS \\
\hline $\begin{array}{l}\text { Macroeconomic and } \\
\text { political data }\end{array}$ & $\begin{array}{c}\cdot \text { Country GDP } \\
\cdot \text { Country GDP per capita } \\
\cdot \quad \text { Political risk } \\
\cdot \text { Commercial risk } \\
\cdot \quad \text { Country risk } \\
\cdot \text { Economic growth } \\
\cdot \text { Population size } \\
\cdot \quad \text { Unemployment rate } \\
\cdot \quad \text { Economically active population (working) } \\
\cdot \quad \text { Population density } \\
\cdot \quad \text { Average age }\end{array}$ \\
\hline Purchasing power & $\begin{array}{c}\cdot \quad \text { Inflation } \\
\cdot \quad \text { GDP PPP } \\
\cdot \quad \text { GDP PPP per capita } \\
\cdot \quad \text { Minimum salary } \\
\cdot \quad \text { Average salary }\end{array}$ \\
\hline Trade indicators & 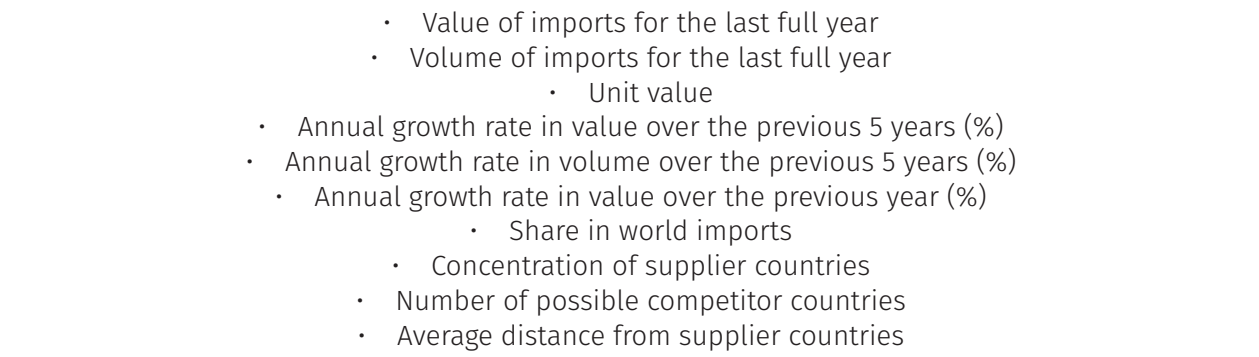 \\
\hline $\begin{array}{l}\text { Commercial } \\
\text { relationship between } \\
\text { country of origin and } \\
\text { target countries }\end{array}$ & $\begin{array}{c}\text { - Total value of exports from country of origin for the previous year (in thousands of USD) } \\
\text { the countries under study } \\
\text { - Annual growth rate in value over the previous year of exports from the country of origin to the } \\
\text { countries under study } \\
\text { Trade partner ranking }\end{array}$ \\
\hline $\begin{array}{l}\text { Cultural environment } \\
\text { and consumption } \\
\text { structure }\end{array}$ & $\begin{array}{c}\text {. Language } \\
\text { Number of cultural barriers } \\
\cdot \quad \text { Per capita demand } \\
\text { - Exporting country's share in imports of target country } \\
\text { - Approximate number of inhabitants over } 65 \text { years old } \\
\text { - Approximate number of inhabitants with gluten intolerance } \\
\text {. Approximate number of vegetarians }\end{array}$ \\
\hline $\begin{array}{l}\text { Legal and fiscal } \\
\text { considerations }\end{array}$ & $\begin{array}{c}\text {. General value-added tax } \\
\text {. } \quad \text { Value-added tax for export product } \\
\cdot \text {. Duration of copyright protection (design) }\end{array}$ \\
\hline Public services & $\begin{array}{l}\text { - Number of international commercial airports } \\
\text {. Number of international commercial ports }\end{array}$ \\
\hline
\end{tabular}

Source: Own elaboration. 
low; A2 low; A3 quite acceptable; A4 acceptable; B significant; $C$ high; D very high; E extreme. As can be observed, COFACE uses an eight-level scale to assess risk. In order to assign a numerical value to country risk in Table VI, the lowest risk was assigned the highest numerical value, 8 in this case, and the highest risk the lowest, i.e. 1. A country with an A1 qualification, for example, is assigned a numerical value of 8 , one with an $A 2$ qualification a 7 , and so on.

Subsequently, a $1 \%$ - $3 \%$ weighting was used in Table VII 3\% was used for those indicators directly pertaining to international trade in the subheading 1207.99 in the year 2016 and the value of exports from Ecuador to the European Union. 2\% was used for indicators directly pertaining to imports in the mentioned subheading but making reference to a period of several years, and those indicators relating to the concentration of supplier countries and country risk. A $1 \%$ weighting was assigned to those that do not directly or indirectly relate to the subheading in question.

Once the weighting had been applied to each indicator, the weighting was multiplied by the Base 10 value for each indicator, which resulted in the weighted Base 10 value as shown in Table VIII.

The sum of the weighted Base 10 values of the different indicators results in ranking 1 and ranking 2, and the sum of those produces the final ranking, which is presented in Table VIII and, according to which, the three preselected countries are: Germany with a score of 2,167 points, Spain with 1,733 points and the Netherlands with 1,717 points.

\section{Market research}

Once the three pre-selected countries had been obtained, in-depth research was carried out on each of them, where data relating to the politico-economic, legal and cultural environment, demand for chia seeds and entry barriers were collected and market analyses were conducted. The data gathered in this stage are shown in the market selection phase.

\section{Selection of most suitable market}

During the third stage, in order to select the most suitable market, the analitico-quantitative indicators established in the pre-selection phase as well as during the in-depth study of each pre-selected country were compared, evaluating the 7 dimensions through a weighted matrix (see Table IX, results section).

Each analitico-quantitative indicator was valued against the maximum value registered in each one of the countries under study and converted to a base 10 number using the same parameters as for the market pre-selection frame, the exception being the subcriteria whose maximum value represented the least adequate value. In these cases, the formula was reversed, i.e. the lowest value was assigned a 10 as base 10 value.

This was done in order to assess the importance of the data in a unified scale. It is also worth noting that the indicators were given a maximum weighting of $3 \%$ and a minimum weighting of $1 \%$ in order to produce final results on a scale of $100 \%$. This weighting was chosen following the researchers own criteria and depending on the relative importance individual criteria have for the specific product in question, in this particular case the chia seeds (find in the Appendix a guide explaining the assessment process, detailing how the results in Table IX were obtained). 


\begin{tabular}{|c|c|c|c|c|c|c|c|c|c|c|c|c|c|c|c|c|c|c|c|c|c|c|c|c|c|c|c|c|c|}
\hline \multirow{6}{*}{ 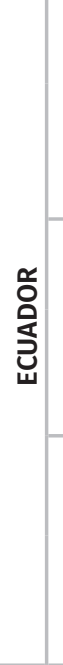 } & \multirow{2}{*}{ 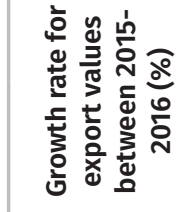 } & ֻّ & $T$ & $\tau$ & $T$ & $T$ & $\sim$ & - & $\tau$ & $m$ & $T$ & - & $\tau$ & t & $\tau$ & - & & $T$ & & $\circ$ & - & $T$ & $\sim$ & ז & $\uparrow-$ & - & $\tau$ & $T$ & \\
\hline & & 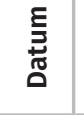 & $\Upsilon$ & $\mathbb{i}$ & $\stackrel{\infty}{\tau}$ & น & $\stackrel{\Omega}{\wedge}$ & $\stackrel{ \pm}{\sim}$ & $\stackrel{ \pm}{\sim}$ & \% & $\pi$ & $\stackrel{m}{F}$ & $\stackrel{\mathscr{N}}{i}$ & $\stackrel{\mathcal{P}}{\leftarrow}$ & t & $\approx$ & $\stackrel{8}{0}$ & $\stackrel{\infty}{\tau}$ & $\bar{x}$ & જे & $\checkmark$ & $\stackrel{m}{m}$ & 字 & \begin{tabular}{c|c}
$\infty$ & \multicolumn{2}{c}{} \\
1 &
\end{tabular} & 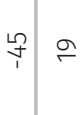 & $=-$ & $\sim$ & $\approx$ & $\stackrel{\widehat{\vartheta}}{\Im}$ \\
\hline & \multirow{2}{*}{ 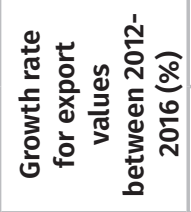 } & 苂으 & $\tau$ & $\tau$ & $T$ & - & $\sim$ & $\sim$ & $T$ & $T$ & 0 & 0 & $\circ$ & $r$ & $\tau$ & - & $\sim$ & $\checkmark$ & $T$ & - & - & ${ }_{1}^{+}$ & $\sim$ & -7 & \begin{tabular}{c|c} 
& -
\end{tabular} & $m$ & $\sim$ & $\sim$ & \\
\hline & & 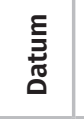 & 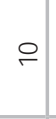 & $\bar{\tau}$ & $\overbrace{1}^{+}$ & $\sim$ & $\bar{\lambda}$ & $\stackrel{\mathscr{N}}{\sim}$ & $\begin{array}{l}\infty \\
1 \\
1\end{array}$ & $\overline{1}$ & $\stackrel{\infty}{\infty}$ & 0 & $\stackrel{尺}{尺}$ & $\infty$ & $\sim$ & 0 & $\approx$ & ติ & 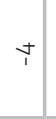 & 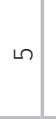 & \pm & 号 & $\bar{m}$ & \begin{tabular}{lll}
0 & \multicolumn{1}{|c}{}
\end{tabular} & $\stackrel{n}{\tau} \sim \sim$ & 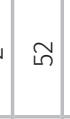 & $\stackrel{ \pm}{\sim}$ & $\approx$ & $\hat{\nexists}$ \\
\hline & \multirow{2}{*}{ 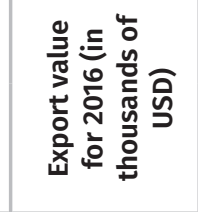 } & 岕。 & 으 & $r$ & $t$ & $\tau$ & - & - & $r$ & $\tau$ & $\tau$ & ? & - & $r$ & 0 & - & - & - & $\sigma$ & $r$ & - & - & - & $\infty \quad$ & $-r$ & - & $r$ & - & \\
\hline & & 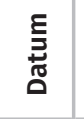 & 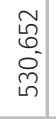 & $\overline{8}$ & 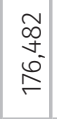 & $\begin{array}{l}\stackrel{2}{\alpha} \\
\underset{5}{F} \\
F\end{array}$ & 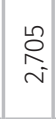 & 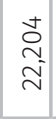 & $\begin{array}{l}\bar{\sigma} \\
\bar{q} \\
q\end{array}$ & 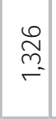 & \begin{tabular}{l}
0 \\
0 \\
$\infty$ \\
\multirow{\sim}{*}{}
\end{tabular} & 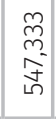 & $\begin{array}{l}\text { t } \\
0 \\
f \\
f\end{array}$ & 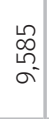 & $\begin{array}{c}\mathfrak{g} \\
\hat{\sigma} \\
o \\
\sim \\
\sim\end{array}$ & $\stackrel{\circ}{\stackrel{0}{n-j}}$ & $\bar{\varnothing}$ & $\begin{array}{c}\stackrel{+}{0} \\
\text { m. }\end{array}$ & $\begin{array}{l}m \\
\\
o \\
o \\
o\end{array}$ & 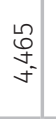 & 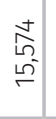 & $f$ & 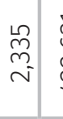 & 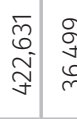 & 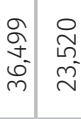 & $\begin{array}{c}\widetilde{N} \\
\sim \\
\sigma \\
\sigma\end{array}$ & $\begin{array}{l}\Re \\
\hat{\sigma} \\
\sigma\end{array}$ & 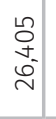 & $\begin{array}{c}m \\
m \\
\sim \\
\sim \\
\sim \\
\sim\end{array}$ \\
\hline \multirow{12}{*}{ 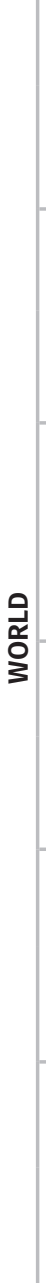 } & \multirow{2}{*}{ 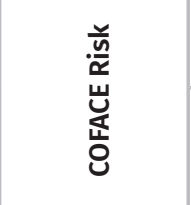 } & 芯。 & $\circ$ & 으 & $a$ & $\wedge$ & $\llcorner\cap$ & Ln & $a$ & $\infty$ & $\infty$ & $\infty$ & $\sigma$ & $\infty$ & $a$ & $ナ$ & $\wedge$ & $\infty$ & $\infty$ & $\infty$ & $\infty$ & $\circ$ & a & $a \mid \infty$ & \begin{tabular}{l|l}
$\infty$ & -
\end{tabular} & $a$ & $\wedge$ & $\stackrel{\circ}{\circ}$ & \\
\hline & & 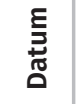 & $\infty$ & $\infty$ & $\wedge$ & \llcorner & t & $\checkmark$ & $\wedge$ & 0 & 0 & 0 & $\wedge$ & 0 & $\lambda$ & $m$ & \llcorner & 0 & 0 & 0 & 0 & $\infty$ & $\wedge$ & 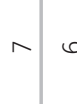 & \begin{tabular}{l|l}
0 & ก
\end{tabular} & $\wedge$ & \llcorner & $\infty$ & $\infty$ \\
\hline & \multirow{2}{*}{ 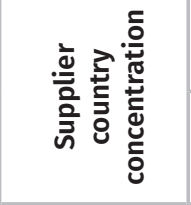 } & 亗。 & $\checkmark$ & $\llcorner\cap$ & t & เn & in & 0 & 으 & 0 & 0 & $m$ & レ & 0 & レ & \llcorner & 0 & เ & 几 & - & $n$ & $m$ & ナ & $m m$ & $m \sim$ & $m$ & \llcorner & 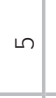 & \\
\hline & & 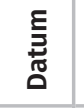 & $\stackrel{\overbrace{}}{0}$ & ণి & $\stackrel{\Re}{0}$ & 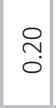 & $\underset{\tilde{O}}{\tilde{O}}$ & $\stackrel{0}{\circ}$ & : & 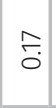 & f. & 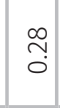 & స్ర & $\stackrel{\text { I }}{\text { ○े }}$ & ঙ্ণ & 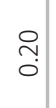 & $\stackrel{\llcorner}{\circ}$ & ָ̃ & $\frac{\circ}{\partial}$ & 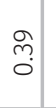 & $\stackrel{7}{0}$ & $\stackrel{\infty}{\sim}$ & $\begin{array}{c}\stackrel{ \pm}{\Delta} \\
\stackrel{0}{0}\end{array}$ & $\stackrel{\infty}{\stackrel{\infty}{0}}$ & 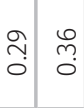 & i & 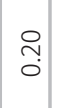 & $\stackrel{\circ}{\check{\sigma}}$ & $\stackrel{\text { ? }}{0}$ \\
\hline & \multirow{2}{*}{ 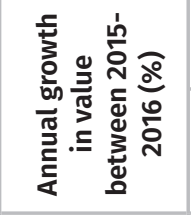 } & 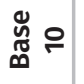 & $T$ & $T$ & - & ㅇ & $r$ & $T$ & 0 & $\sim$ & $T$ & $T$ & $T$ & $\sim$ & $\sim$ & $T$ & $r$ & $r$ & - & - & เn & - & $T$ & $T$ & $T \tau$ & $1-$ & $T$ & $\uparrow$ & \\
\hline & & 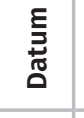 & $\uparrow$ & 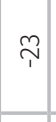 & t & స & $\simeq$ & $\tau$ & 0 & 文 & $r$ & $\widetilde{\sim}$ & $\stackrel{\varphi}{\tau}$ & $\stackrel{\infty}{\sim}$ & $\mathcal{F}$ & $\div$ & 0 & $m$ & $f$ & $f$ & §ิ & $\stackrel{\infty}{\sim}$ & 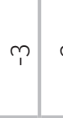 & \begin{tabular}{llll}
$\tau$ & \multicolumn{1}{l}{}
\end{tabular} & $\stackrel{\varphi}{\varphi}$ & 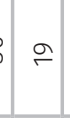 & $T$ & & $\lesssim$ \\
\hline & \multirow{2}{*}{ 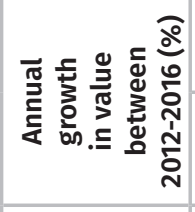 } & $\begin{array}{l}\stackrel{\Xi}{\nu} \circ \\
\tilde{D}^{\circ}\end{array}$ & ง & t & - & 0 & $m$ & t & 0 & $a$ & $\sim$ & t & $\stackrel{\circ}{\circ}$ & $\stackrel{\circ}{\sim}$ & 0 & $\sim$ & $\checkmark$ & $\llcorner\cap$ & 0 & $\infty$ & $m$ & 0 & + & \begin{tabular}{l|l}
$n$ & \llcorner
\end{tabular} & ๓ $\sim$ & $m$ & 0 & $r$ & \\
\hline & & 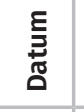 & ঃ & $\stackrel{\sim}{\sim}$ & - & $\stackrel{+}{m}$ & 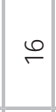 & $\stackrel{\infty}{\stackrel{\infty}{*}}$ & 0 & $\bar{n}$ & $\circ$ & $\stackrel{\infty}{\simeq}$ & $\stackrel{\infty}{\curvearrowleft}$ & in & পి & $\infty$ & $\approx$ & নి & $\approx$ & 导 & $\simeq$ & $\approx$ & 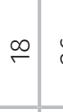 & $\stackrel{\sim}{ } \approx$ & $\lesssim a$ & $\stackrel{m}{\sim}$ & 0 & $m$ & $\stackrel{\infty}{\curvearrowleft}$ \\
\hline & \multirow{2}{*}{ 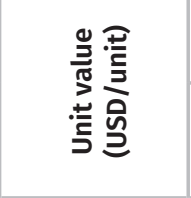 } & 岕 & \llcorner & 0 & $\checkmark$ & $\checkmark$ & t & 0 & 0 & $\infty$ & 0 & $m$ & $\infty$ & $\infty$ & 0 & $\checkmark$ & $\checkmark$ & เn & + & 6 & t & $\stackrel{\circ}{\circ}$ & ナ & \begin{tabular}{l|l|l|l}
$n$ & $\sim$
\end{tabular} & $\backsim m$ & $\begin{array}{ll}n \\
\end{array}$ & \llcorner & 0 & \\
\hline & & 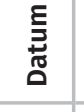 & $\begin{array}{c}\text { Dे } \\
\sim \\
\sim\end{array}$ & $\stackrel{\infty}{\stackrel{0}{m}}$ & $\stackrel{\stackrel{n}{\sigma}}{\stackrel{\sigma}{二}}$ & 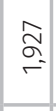 & $\stackrel{\infty}{\stackrel{\infty}{v}}$ & 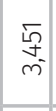 & 0 & 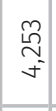 & ' & 茎 & 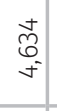 & 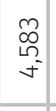 & 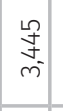 & $\begin{array}{l}m \\
\stackrel{\alpha}{\sigma} \\
\leftarrow\end{array}$ & $\begin{array}{l}\stackrel{0}{\circ} \\
\stackrel{\sim}{\sim}\end{array}$ & $\begin{array}{c}\stackrel{0}{\sim} \\
\sim \\
\sim \\
\sim\end{array}$ & $\begin{array}{l}0 \\
0 \\
0 \\
i\end{array}$ & $\stackrel{\infty}{\stackrel{\infty}{m}}$ & $\underset{\substack{0 \\
\sim}}{\stackrel{0}{*}}$ & 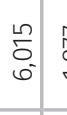 & 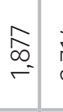 & 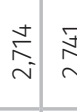 & 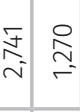 & $=\stackrel{\substack{\mathcal{S} \\
\stackrel{S}{\sim}}}{\sim}$ & 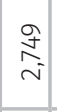 & $\begin{array}{c}\stackrel{n}{n} \\
\stackrel{n}{n} \\
m\end{array}$ & $\begin{array}{l}\frac{n}{0} \\
0 \\
0\end{array}$ \\
\hline & \multirow{2}{*}{ 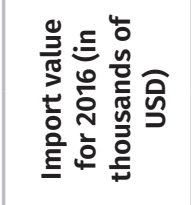 } & 芯ㅇ & 우 & + & $\sim$ & - & $r$ & $r$ & 0 & - & $\tau$ & t & - & $r$ & $m$ & $r$ & $r$ & $r$ & $\sim$ & $\tau$ & $r$ & $r$ & - & $0-7$ & $\tau$ & - & $r$ & - & \\
\hline & & 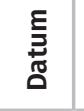 & $\begin{array}{l}\stackrel{m}{\sigma} \\
\infty^{0} \\
\stackrel{\sim}{\sim}\end{array}$ & 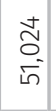 & $\begin{array}{l}\infty \\
0 \\
0 \\
\llcorner \\
\sim \\
\leftarrow\end{array}$ & 足 & 寺 & $\begin{array}{l}\text { î } \\
\text { in }\end{array}$ & 0 & $\mid \begin{array}{l}\infty \\
0 \\
0 \\
+\end{array}$ & 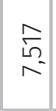 & 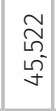 & ก & $\begin{array}{l}\infty \\
\stackrel{\infty}{\rho} \\
\mathrm{m}\end{array}$ & $\begin{array}{l}0 \\
0 \\
0 \\
0 \\
0 \\
0\end{array}$ & 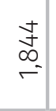 & $\begin{array}{l}\stackrel{0}{7} \\
\underset{f}{f}\end{array}$ & 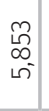 & 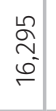 & 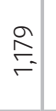 & 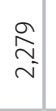 & চ్ & $\widehat{\stackrel{m}{\imath}}$ & 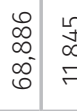 & 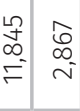 & $\begin{array}{l}0 \\
\vdots \\
\sigma \\
\sigma\end{array}$ & 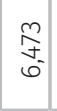 & $\begin{array}{l}\tilde{O} \\
\tilde{O} \\
\stackrel{\circ}{\circ}\end{array}$ & $\begin{array}{l}\stackrel{m}{\sigma} \\
o D^{-} \\
\stackrel{\sim}{\sim}\end{array}$ \\
\hline & 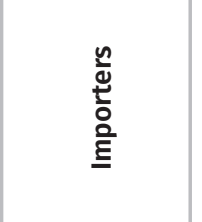 & & 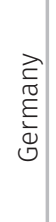 & 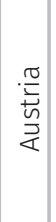 & 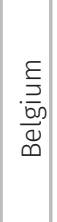 & 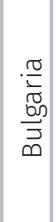 & $\mid \begin{array}{l}n \\
\frac{n}{2} \\
\grave{3}\end{array}$ & 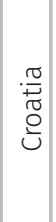 & 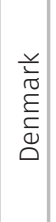 & 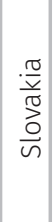 & $\mid \begin{array}{l}\frac{0}{c} \\
\frac{0}{0} \\
\frac{0}{0} \\
\frac{0}{n}\end{array}$ & $\mid \begin{array}{l}\frac{c}{\pi} \\
\stackrel{0}{\Omega} \\
\sim\end{array}$ & 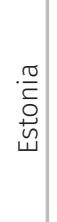 & 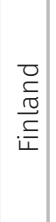 & 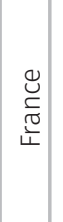 & 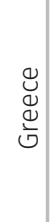 & 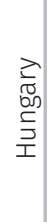 & $\frac{\frac{c}{0}}{\underline{\underline{d}}}$ & $\frac{7}{\mathbb{\pi}}$ & 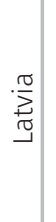 & | & 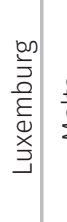 & $\frac{\frac{\pi}{5}}{\frac{\pi}{2}}$ & 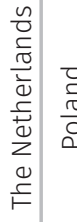 & 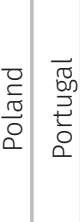 & 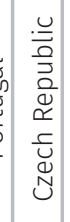 & 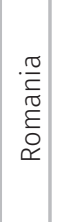 & & 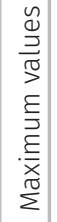 \\
\hline
\end{tabular}




\begin{tabular}{|c|c|c|c|c|c|c|c|c|c|c|c|c|c|c|c|c|c|c|c|c|c|c|c|c|c|c|c|}
\hline & & है & $\sim$ & 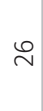 & $\infty$ & $\approx$ & $\digamma$ & $\stackrel{ \pm}{\longleftarrow}$ & $\approx$ & $F$ & $a$ & - & $\wedge$ & $a$ & n 7 & $=\approx$ & $\stackrel{ \pm}{\longleftarrow}$ & $m$ & 0 & $=7$ & 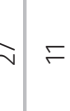 & 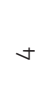 & $\stackrel{\stackrel{\sim}{\sim}}{\sim}$ & $\mp$ & $F$ & 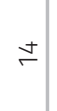 & $\bar{\sim}$ \\
\hline & 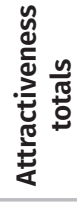 & 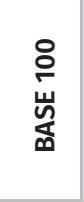 & $\begin{array}{l}\stackrel{\circ}{0} \\
- \\
-\end{array}$ & $\stackrel{m}{\varphi}$ & $\stackrel{m}{m}$ & $\stackrel{8}{\circ}$ & $\stackrel{\widetilde{m}}{\sim}$ & 이 & $\stackrel{\circ}{\circ}$ & $\underline{\sigma}$ & 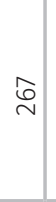 & 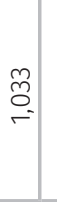 & d & $\stackrel{\grave{v}}{\sim}$ & $\vec{b}$ & $\therefore \stackrel{\circ}{\circ}$ & ঐి & ৪̀ & $\begin{array}{l}0 \\
0 \\
+\end{array}$ & 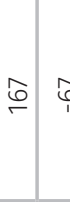 & i. & ০ి & 0 & $\underline{6}$ & 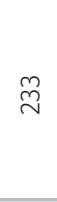 & ஓ্ণ & $\stackrel{m}{m}$ \\
\hline & 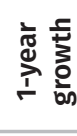 & 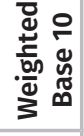 & $T$ & $\tau$ & $T$ & $T$ & $\sim$ & $\tau$ & - & $m$ & $T$ & - & $\uparrow$ & $\checkmark$ & -7 & $-\tau$ & $T$ & - & $\stackrel{\circ}{\circ}$ & -7 & $\sim$ & $T$ & $\tau$ & $r$ & $r$ & $r$ & $T$ \\
\hline & 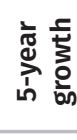 & 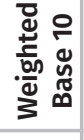 & - & $\tau$ & $T$ & $\tau$ & $\sim$ & $\sim$ & $T$ & $T$ & 0 & 0 & $\stackrel{ }{\circ}$ & $r$ & $\tau$ & $-\sim$ & $\checkmark$ & $T$ & - & - & $\sim$ & $r$ & $T$ & - & $m$ & $\sim$ & $\sim$ \\
\hline & $\begin{array}{l}\frac{t}{2} \\
\frac{0}{x} \\
\frac{0}{\pi}\end{array}$ & 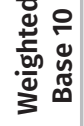 & m & $m$ & 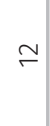 & $m$ & $m$ & $m$ & $m$ & $m$ & $m$ & m & $m$ & $m$ & 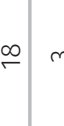 & $\begin{array}{l}n \\
n\end{array}$ & $m$ & $\widehat{\sim}$ & $m$ & $m \sim$ & $m m$ & $\stackrel{ \pm}{\sim}$ & $m$ & $m$ & $m$ & $m$ & $m$ \\
\hline
\end{tabular}

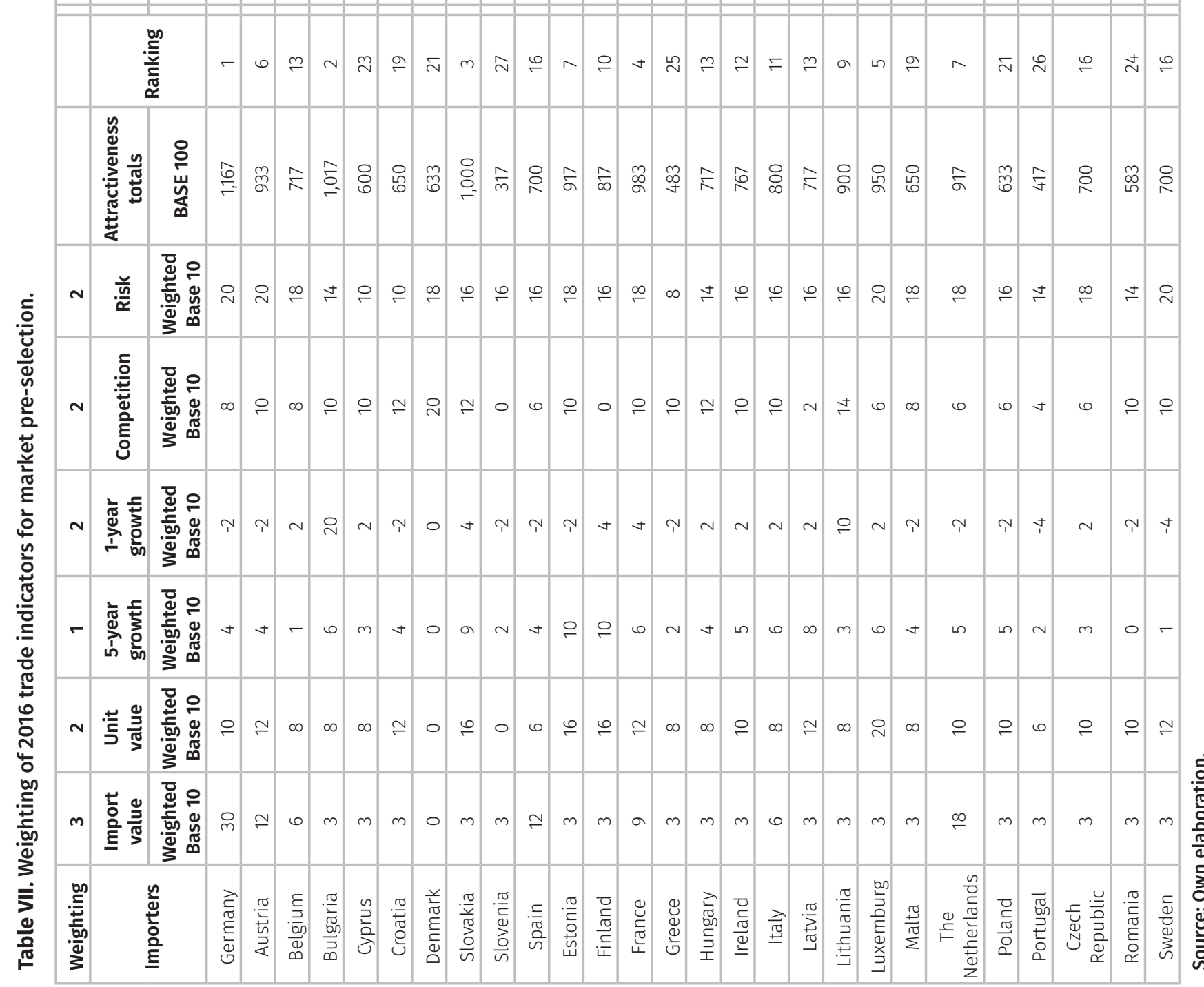


Table VIII. Ranking of the EU countries for Ecuadorian chia seed export market pre-selection.

\begin{tabular}{|c|c|c|c|c|}
\hline Ranking & Country & Combined & World & Ecuador \\
\hline 1 & Germany & 2,167 & 1,167 & 1,000 \\
\hline 2 & Spain & 1,733 & 700 & 1,033 \\
\hline 3 & $\begin{array}{c}\text { The } \\
\text { Netherlands }\end{array}$ & 1,717 & 917 & 800 \\
\hline 4 & Italy & 1,700 & 800 & 900 \\
\hline 5 & France & 1,650 & 983 & 667 \\
\hline 6 & Estonia & 1,283 & 917 & 367 \\
\hline 7 & Latvia & 1,183 & 717 & 467 \\
\hline 8 & Slovakia & 1,167 & 1,000 & 167 \\
\hline 9 & Bulgaria & 1,117 & 1,017 & 100 \\
\hline 10 & Finland & 1,083 & 817 & 267 \\
\hline 11 & Lithuania & 1,067 & 900 & 167 \\
\hline 12 & Belgium & 1,050 & 717 & 333 \\
\hline 13 & Ireland & 967 & 767 & 200 \\
\hline 14 & $\begin{array}{c}\text { Czech } \\
\text { Republic }\end{array}$ & 933 & 700 & 233 \\
\hline 15 & Austria & 900 & 933 & -33 \\
\hline 16 & Luxemburg & 883 & 950 & -67 \\
\hline 17 & Malta & 882 & 650 & 233 \\
\hline 18 & Croatia & 850 & 650 & 200 \\
\hline 19 & Cyprus & 833 & 600 & 233 \\
\hline 20 & Sweden & 831 & 700 & 133 \\
\hline 21 & Hungary & 817 & 717 & 100 \\
\hline 22 & Romania & 783 & 583 & 200 \\
\hline 23 & Denmark & 733 & 633 & 100 \\
\hline 24 & Greece & 650 & 483 & 167 \\
\hline 25 & Poland & 633 & 633 & 0 \\
\hline 26 & Portugal & 583 & 417 & 167 \\
\hline 27 & Slovenia & 583 & 317 & 267 \\
\hline
\end{tabular}

Source: Own elaboration.

\section{RESULTS}

As can be observed in Table IX, macroeconomic and political data were analysed by means of indicators such as, among others, GDP, GDP per capita, various types of risk, economic growth, and unemployment rate. With a possible maximum value of $27 \%$ Germany obtained $24.20 \%$, the Netherlands $18.80 \%$ and Spain $18.10 \%$. In terms of purchasing power, which was evaluated out of a maximum of $13 \%$ and through indicators such as inflation, average salary, minimum salary, etc., Germany scored $10.00 \%$, the Netherlands $8.80 \%$ and Spain $8.70 \%$.

The dimension focusing on trade indicators received a maximum score of $24.00 \%$, out of which Germany obtained $21.20 \%$, the Netherlands $19.30 \%$ and Spain $12.90 \%$. In the next dimension, which reflects the relationship between Ecuador and all the other pre-selected countries, Spain obtained 5.40\%, Germany $4.20 \%$ and the Netherlands $2.20 \%$ out of a possible maximum of $7 \%$.

The dimension relating to the cultural environment and consumption structure was weighted at $17 \%$ using, among others, indicators such as language, entry barriers, per capita demand. Spain scored $10.20 \%$, Germany and the Netherlands both $6.20 \%$ in this category. When it comes to the dimension of legal and fiscal considerations, which is weighted at $8 \%$, Spain obtained $6.40 \%$, the Netherlands $6.10 \%$ and Germany $5.80 \%$ by evaluating indicators such as general VAT, VAT rate for chia seeds as well as indicators relating to intellectual property rights. In the last criterion, the one pertaining to public services, weighted at $4 \%$, indicators such as the number of ports or international cargo airports were evaluated. Spain scored $4.00 \%$, Germany $3.00 \%$ and the Netherlands $2.20 \%$.

Once each one of the indicators and dimensions had been evaluated, the final result could be obtained out of a total possible weighted score of $100 \%$. Germany scored $70.40 \%$, the Netherlands $61.40 \%$ and Spain $60.30 \%$, which leads to the conclusion that Germany is the country with the greatest market potential for the export of Ecuadorian chia seeds. It is worth mentioning that Germany won with a $9.00 \%$ lead over the Netherlands and a 10.10\% lead over Spain, but that the difference between the Netherlands and Spain as a second choice was of a mere $1.10 \%$. 
Table IX. Target market selection for the export of Ecuadorian chia seeds.

\begin{tabular}{|c|c|c|c|c|c|c|c|c|c|c|c|}
\hline \multirow{2}{*}{ Criteria } & \multirow{2}{*}{ Weighting } & \multicolumn{2}{|c|}{ Germany } & \multicolumn{2}{|c|}{ The netherlands } & \multicolumn{2}{|l|}{ Spain } & \multirow{2}{*}{$\begin{array}{l}\text { Maximum } \\
\text { value }\end{array}$} & Germany & $\begin{array}{c}\text { The } \\
\text { netherlands }\end{array}$ & Spain \\
\hline & & Datum & $\begin{array}{c}\text { Base } \\
10\end{array}$ & Datum & $\begin{array}{c}\text { Base } \\
10\end{array}$ & Datum & $\begin{array}{c}\text { Base } \\
10\end{array}$ & & \multicolumn{3}{|c|}{ Result } \\
\hline $\begin{array}{c}\text { Macroeconomic } \\
\text { and political } \\
\text { data }\end{array}$ & $27 \%$ & & & & & & & & $24.20 \%$ & $18.80 \%$ & $18.10 \%$ \\
\hline $\begin{array}{l}\text { GDP } 2016 \\
\text { (billions of } \\
\text { euros) }\end{array}$ & $3.00 \%$ & $3,132,670$ & 10 & 697,219 & 3 & $1,113,851$ & 4 & $3,132,670$ & $3.00 \%$ & $0.90 \%$ & $1.20 \%$ \\
\hline $\begin{array}{l}\text { GDP per capita } \\
2016 \text { (thousands } \\
\text { of dollars) }\end{array}$ & $3.00 \%$ & 37,900 & 10 & 40,900 & 10 & 24,000 & 6 & 40,900 & $3.00 \%$ & $3.00 \%$ & $1.80 \%$ \\
\hline $\begin{array}{l}\text { Political risk } \\
\text { (CESCE) }\end{array}$ & $3.00 \%$ & Very stable & 10 & Very stable & 10 & Very stable & 10 & 10 & $3.00 \%$ & $3.00 \%$ & $3.00 \%$ \\
\hline $\begin{array}{c}\text { Commercial risk } \\
\text { (CESCE) }\end{array}$ & $3.00 \%$ & Favourable & 8 & Favourable & 8 & Favourable & 8 & 0 & $2.40 \%$ & $2.40 \%$ & $2.40 \%$ \\
\hline $\begin{array}{l}\text { Country risk } \\
2016 \text { (COFACE) }\end{array}$ & $3.00 \%$ & A1 & 10 & $\mathrm{~A} 2$ & 9 & $\mathrm{~A} 3$ & 8 & $\mathrm{~A} 1$ & $3.00 \%$ & $2.70 \%$ & $2.40 \%$ \\
\hline $\begin{array}{l}\text { Economic } \\
\text { growth } 2016\end{array}$ & $3.00 \%$ & $1.90 \%$ & 6 & $2.20 \%$ & 7 & $3.20 \%$ & 10 & $3.20 \%$ & $1.80 \%$ & $2.10 \%$ & $3.00 \%$ \\
\hline Population 2016 & $3.00 \%$ & $82,313,559$ & 10 & $17,097,538$ & 3 & $42,019,525$ & 6 & $82,313,559$ & $3.00 \%$ & $0.90 \%$ & $1.80 \%$ \\
\hline $\begin{array}{c}\text { Unemployment } \\
\text { rate } 2016\end{array}$ & $2.00 \%$ & $4.3 \%$ & 7 & $6.70 \%$ & 6 & $18.60 \%$ & 0 & $18.60 \%$ & $1.40 \%$ & $1.20 \%$ & $0.00 \%$ \\
\hline $\begin{array}{l}\text { Economically } \\
\text { active } \\
\text { population } 2016 \\
\text { (working) }\end{array}$ & $2.00 \%$ & $40,895,414$ & 10 & $8,429,002$ & 3 & $22,745,900$ & 6 & $40,895,414$ & $2.00 \%$ & $0.60 \%$ & $1.20 \%$ \\
\hline $\begin{array}{l}\text { Population } \\
\text { density }\end{array}$ & $1.00 \%$ & 230,55 & 6 & 411,56 & 10 & 92,03 & 3 & 411,56 & $0.60 \%$ & $1.00 \%$ & $0.30 \%$ \\
\hline Average age & $1.00 \%$ & 40,3 & 10 & 39 & 10 & 39 & 10 & 40 & $1.00 \%$ & $1.00 \%$ & $1.00 \%$ \\
\hline $\begin{array}{l}\text { PURCHASING } \\
\text { POWER }\end{array}$ & $13 \%$ & & & & & & & & $10.00 \%$ & $8.80 \%$ & $8.70 \%$ \\
\hline Inflation 2016 & $3.00 \%$ & $0.40 \%$ & 0 & $0.10 \%$ & 3 & $-0.30 \%$ & 8 & $0.40 \%$ & $0.00 \%$ & $0.90 \%$ & $2.40 \%$ \\
\hline $\begin{array}{l}\text { GDP PPP } 2016 \\
\text { (billions of } \\
\text { dollars) }\end{array}$ & $3.00 \%$ & $3,924,035$ & 10 & 840,000 & 3 & $1,621,190$ & 5 & $3,924,035$ & $3.00 \%$ & $0.90 \%$ & $1.50 \%$ \\
\hline $\begin{array}{l}\text { GDP PPP per } \\
\text { capita } 2016 \\
\text { (billions of } \\
\text { dollars) }\end{array}$ & $3.00 \%$ & 48,041 & 10 & 49,587 & 10 & 34,906 & 8 & 49,587 & $3.00 \%$ & $3.00 \%$ & $2.40 \%$ \\
\hline $\begin{array}{c}\text { Minimum salary } \\
2017 \text { (Euros) }\end{array}$ & $2.00 \%$ & 1498.00 & 10 & 1551.60 & 10 & 825.70 & 6 & $1,551.60$ & $2.00 \%$ & $2.00 \%$ & $1.20 \%$ \\
\hline $\begin{array}{l}\text { Average salary } \\
\text { (Euros per } \\
\text { month) }\end{array}$ & $2.00 \%$ & 3920.00 & 10 & 4238.00 & 10 & 2188.25 & 6 & 4.238 .00 & $2.00 \%$ & $2.00 \%$ & $1.20 \%$ \\
\hline $\begin{array}{c}\text { TRADE } \\
\text { INDICATORS }\end{array}$ & $24 \%$ & & & & & & & & $21.20 \%$ & $19.30 \%$ & $12.90 \%$ \\
\hline $\begin{array}{l}\text { Import value } \\
2016 \text { (tariff } \\
\text { subheading } \\
1207.99 \text { ) }\end{array}$ & $3.00 \%$ & 128,013 & 10 & 68,886 & 6 & 45,522 & 4 & 128,013 & $3.00 \%$ & $1.80 \%$ & $1.20 \%$ \\
\hline
\end{tabular}




\begin{tabular}{|c|c|c|c|c|c|c|c|c|c|c|c|}
\hline \multirow{2}{*}{ Criteria } & \multirow{2}{*}{ Weighting } & \multicolumn{2}{|c|}{ Germany } & \multicolumn{2}{|c|}{ The netherlands } & \multirow{2}{*}{$\begin{array}{l}\text { Spain } \\
\text { Datum }\end{array}$} & \multirow[b]{2}{*}{$\begin{array}{c}\text { Base } \\
10\end{array}$} & \multirow{2}{*}{$\begin{array}{l}\text { Maximum } \\
\text { value }\end{array}$} & Germany & $\begin{array}{c}\text { The } \\
\text { netherlands }\end{array}$ & Spain \\
\hline & & Datum & $\begin{array}{c}\text { Base } \\
10\end{array}$ & Datum & $\begin{array}{c}\text { Base } \\
10\end{array}$ & & & & \multicolumn{3}{|c|}{ Result } \\
\hline $\begin{array}{l}\text { Import unit } \\
\text { value (per } \\
\text { metric tonne) }\end{array}$ & $3.00 \%$ & 2,829 & 10 & 2,714 & 10 & 1,543 & 6 & 2,829 & $3.00 \%$ & $3.00 \%$ & $1.80 \%$ \\
\hline $\begin{array}{l}\text { Annual growth } \\
\text { in value } \\
\text { between 2015- } \\
2016(\%)\end{array}$ & $3.00 \%$ & -7 & 6 & -2 & 9 & -23 & 0 & -23 & $1.80 \%$ & $2.70 \%$ & $0.00 \%$ \\
\hline $\begin{array}{c}\text { Imported } \\
\text { volume } 2016 \\
\text { (metric tonnes) }\end{array}$ & $3.00 \%$ & 45,256 & 10 & 25,382 & 6 & 29,503 & 7 & 45,256 & $3.00 \%$ & $1.80 \%$ & $2.10 \%$ \\
\hline $\begin{array}{l}\text { Share in world } \\
\text { imports (\% in } \\
\text { 2016) }\end{array}$ & $3.00 \%$ & 13.2 & 10 & 7.1 & 6 & 4.7 & 4 & 13.2 & $3.00 \%$ & $1.80 \%$ & $1.20 \%$ \\
\hline $\begin{array}{l}\text { Annual growth } \\
\text { in value } \\
\text { between 2012- } \\
2016(\%)\end{array}$ & $2.00 \%$ & 20 & 8 & 26 & 10 & 18 & 7 & 26 & $1.60 \%$ & $2.00 \%$ & $1.40 \%$ \\
\hline $\begin{array}{l}\text { Annual growth } \\
\text { in volume } \\
\text { between 2015- } \\
2016(\%)\end{array}$ & $2.00 \%$ & 19 & 10 & 16 & 9 & 10 & 6 & 19 & $2.00 \%$ & $1.80 \%$ & $1.20 \%$ \\
\hline $\begin{array}{c}\text { Supplier } \\
\text { country } \\
\text { concentration }\end{array}$ & $2.00 \%$ & $0.23 \%$ & 9 & $0.28 \%$ & 10 & $0.28 \%$ & 10 & $0.28 \%$ & $1.80 \%$ & $2.00 \%$ & $2.00 \%$ \\
\hline $\begin{array}{l}\text { Number of } \\
\text { possible } \\
\text { competitor } \\
\text { countries }\end{array}$ & $2.00 \%$ & 8 & 0 & 6 & 2 & 8 & 0 & 8 & $0.00 \%$ & $0.40 \%$ & $0.00 \%$ \\
\hline $\begin{array}{c}\text { Average } \\
\text { distance } \\
\text { to supplier } \\
\text { countries }(\mathrm{km})\end{array}$ & $1.00 \%$ & 5,533 & 10 & 5,819 & 10 & 5,454 & 10 & 5,819 & $2.00 \%$ & $2.00 \%$ & $2.00 \%$ \\
\hline $\begin{array}{c}\text { TRADE } \\
\text { RELATIONS } \\
\text { WITH ECUADOR }\end{array}$ & $7 \%$ & & & & & & & & $4.20 \%$ & $2.20 \%$ & $5.40 \%$ \\
\hline $\begin{array}{c}\text { Imports } 2016 \\
\text { (thousands of } \\
\text { USD) }\end{array}$ & $2.00 \%$ & 530,652 & 10 & 422,631 & 8 & 547,333 & 10 & 547,333 & $2.00 \%$ & $1.60 \%$ & $2.00 \%$ \\
\hline $\begin{array}{c}\text { UE trade } \\
\text { partner ranking }\end{array}$ & $2.00 \%$ & 2 & 5 & 4 & 0 & 1 & 7 & 4 & $1.00 \%$ & $0.00 \%$ & $1.40 \%$ \\
\hline $\begin{array}{c}\text { Annual growth } \\
(2015-2016)\end{array}$ & $2.00 \%$ & -3 & 1 & -8 & 0 & 13 & 10 & 13 & $0.20 \%$ & $0.00 \%$ & $2.00 \%$ \\
\hline $\begin{array}{l}\text { Annual growth } \\
\text { in value } \\
\text { between 2012- } \\
2016(\%)\end{array}$ & $1.00 \%$ & 10 & 10 & 6 & 6 & 0 & 0 & 10 & $1.00 \%$ & $0.60 \%$ & $0.00 \%$ \\
\hline $\begin{array}{c}\text { CULTURAL } \\
\text { ENVIRONMENT } \\
\text { AND } \\
\text { CONSUMPTION } \\
\text { STRUCTURE }\end{array}$ & $17 \%$ & & & & & & & & $6.20 \%$ & $6.20 \%$ & $10.20 \%$ \\
\hline
\end{tabular}




\begin{tabular}{|c|c|c|c|c|c|c|c|c|c|c|c|}
\hline \multirow{2}{*}{ Criteria } & \multirow{2}{*}{ Weighting } & \multicolumn{2}{|c|}{ Germany } & \multicolumn{2}{|c|}{ The netherlands } & \multirow{2}{*}{$\begin{array}{l}\text { Spain } \\
\text { Datum }\end{array}$} & \multirow[b]{2}{*}{$\begin{array}{c}\text { Base } \\
10\end{array}$} & \multirow{2}{*}{$\begin{array}{l}\text { Maximum } \\
\text { value }\end{array}$} & Germany & $\begin{array}{c}\text { The } \\
\text { netherlands }\end{array}$ & Spain \\
\hline & & Datum & $\begin{array}{c}\text { Base } \\
10\end{array}$ & Datum & $\begin{array}{c}\text { Base } \\
10\end{array}$ & & & & \multicolumn{3}{|c|}{ Result } \\
\hline Language & $3.00 \%$ & NO & 0 & NO & 0 & YES & 10 & YES & $0.00 \%$ & $0.00 \%$ & $3.00 \%$ \\
\hline $\begin{array}{c}\text { Number of } \\
\text { cultural barriers }\end{array}$ & $3.00 \%$ & 2 & 0 & 2 & 0 & 1 & 5 & 2 & $0.00 \%$ & $0.00 \%$ & $1.50 \%$ \\
\hline $\begin{array}{l}\text { Demand per } \\
\text { capita (in kg) }\end{array}$ & $3.00 \%$ & 0.52 & 4 & 1.48 & 10 & 0.65 & 5 & 1.5 & $1.20 \%$ & $3.00 \%$ & $1.50 \%$ \\
\hline Ecuador's share & $2.00 \%$ & $0.00005 \%$ & 1 & $0.11 \%$ & 10 & $0.002 \%$ & 1 & $0.11 \%$ & $0.20 \%$ & $2.00 \%$ & $0.20 \%$ \\
\hline $\begin{array}{l}\text { Approximate } \\
\text { number of } \\
\text { inhabitants } \\
\text { aged over } 65\end{array}$ & $2.00 \%$ & $17,615,102$ & 10 & $3,351,117$ & 2 & $7,983,710$ & 5 & $17,615,102$ & $2.00 \%$ & $0.40 \%$ & $1.00 \%$ \\
\hline $\begin{array}{l}\text { Approximate } \\
\text { number of } \\
\text { vegetarians } \\
\text { among } \\
\text { population }\end{array}$ & $2.00 \%$ & $8,231,356$ & 10 & 786,487 & 1 & $3,781,757$ & 5 & $8,231,356$ & $2.00 \%$ & $0.20 \%$ & $1.00 \%$ \\
\hline $\begin{array}{l}\text { Approximate } \\
\text { number of } \\
\text { inhabitants } \\
\text { with gluten } \\
\text { intolerance }\end{array}$ & $2.00 \%$ & 823,136 & 4 & 512,926 & 3 & $2,521,172$ & 10 & $2,521,172$ & $0.80 \%$ & $0.60 \%$ & $2.00 \%$ \\
\hline $\begin{array}{l}\text { Legal and fiscal } \\
\text { considerations }\end{array}$ & $8 \%$ & & & & & & & & $5.80 \%$ & $6.10 \%$ & $6.40 \%$ \\
\hline $\begin{array}{l}\text { VAT rate for chia } \\
\text { seeds }\end{array}$ & $3.00 \%$ & $7 \%$ & 6 & $6 \%$ & 7 & $4 \%$ & 8 & $7.00 \%$ & $1.80 \%$ & $2.10 \%$ & $2.40 \%$ \\
\hline $\begin{array}{c}\text { Copyright } \\
\text { protection } \\
\text { period (design) }\end{array}$ & $2.00 \%$ & 5 & 10 & 5 & 10 & 5 & 10 & 5 & $2.00 \%$ & $2.00 \%$ & $2.00 \%$ \\
\hline $\begin{array}{c}\text { Copyright } \\
\text { protection } \\
\text { period (brands) }\end{array}$ & $2.00 \%$ & 10 & 10 & 10 & 10 & 10 & 10 & 10 & $2.00 \%$ & $2.00 \%$ & $2.00 \%$ \\
\hline $\begin{array}{l}\text { General VAT } \\
\text { rate }\end{array}$ & $1.00 \%$ & $19 \%$ & 0 & $21 \%$ & 0 & $21 \%$ & 0 & $21.00 \%$ & $0.00 \%$ & $0.00 \%$ & $0.00 \%$ \\
\hline $\begin{array}{c}\text { PUBLIC } \\
\text { SERVICES }\end{array}$ & $4 \%$ & & 5 & & 7 & & 7 & & $3.00 \%$ & $2.20 \%$ & $4.00 \%$ \\
\hline $\begin{array}{c}\text { Number of } \\
\text { international } \\
\text { commercial } \\
\text { airports }\end{array}$ & $2.00 \%$ & 18 & 6 & 14 & 5 & 31 & 10 & 31 & $1.20 \%$ & $1.00 \%$ & $2.00 \%$ \\
\hline $\begin{array}{l}\text { Number of } \\
\text { international } \\
\text { commercial } \\
\text { ports }\end{array}$ & $2.00 \%$ & 39 & 9 & 24 & 6 & 46 & 10 & 46 & $1.80 \%$ & $1.20 \%$ & $2.00 \%$ \\
\hline TOTAL & $100 \%$ & & & & & & & & $70.40 \%$ & $61.40 \%$ & $60.30 \%$ \\
\hline
\end{tabular}

Source: Own elaboration with data collected from various sources. 
It must also be mentioned that once the final results had been obtained, weightings for some of the indicators were varied, and yet in all the scenarios that were contemplated, Germany always came out on top of the table.

\section{DISCUSSION AND CONCLUSIONS}

Despite the wealth of literature available on the process of market selection, it is commonly agreed that it can be divided into three stages: (1) market pre-selection, (2) in-depth research of the pre-selected markets and (3) selection of most suitable market. In each of these stages, different indicators have to be defined (Sakara et al. 2007). They are not always identical as they depend on the export product in question, which means that they have to be selected or eliminated specifically for each case (Hisrich 2015).

It is, similarly, understood that in terms of methodology different authors concur that when targeting international markets, a systematic selection process is needed in order to establish a ranking of countries considered as possible export destinations (Hisrich 2015). Literature also agrees that a methodology for market selection should contain 5 steps: (1) develop adequate indicators, (2) collect data and convert them into comparable indicators, (3) assign appropriate weighting to each indicator, (4) analyse data and (5) choose the most suitable market from the market ranking (Górecka \& Szałucka 2013, Marchi et al. 2009).

As for the results obtained through the applied methodology, it can be concluded that they are not different from actual reality, as the report "Exporting chia seeds to Europe" by the Dutch Ministry of International Trade points out that Germany is the biggest European importer of chia seeds with a $55 \%$ share, followed by the Netherlands, the United Kingdom and Spain.

This study can help companies, investors and other agents working in foreign trade develop a long-term market vision. With the help of the information obtained in this study, the decision of market selection can be identified, and adequate procedures can be put into practice which will improve the company success and adapt it more closely to the needs of the market destination.

When it comes to the limitations of the methodology, it can be said that it is limited to a selection analysis based on external factors not related to the nature of the company. Another limitation is that a number of indicators used would vary depending on the sector and the export product itself. i.e. no standard indicators are used. This means that every company must select its own specific indicators and assign its own weighting to each of them. Furthermore, in this case study, another limitation is that chia seeds do not possess their own separate tariff subheading and are grouped together with other seeds, which makes it impossible to carry out a fully adequate analysis.

Lastly, it is worth noting that the methodology described in this article can be extrapolated and easily used by companies in search of new markets as well as by institutions whose goal it is to provide consulting and support to promote international expansion. It will also be useful for future research focused on countries and their potential as export destinations, providing a solution to the question of how to select a suitable export market.

\section{REFERENCES}

AYERZA R \& COATES W. 2005. Chia: Rediscovering a Forgotten Crop of the Aztecs. Arizona: The University of Arizona Press. 
BERBEL-PINEDA JM, RAMÓN-JERÓNIMO MA \& VÁZQUEZCARRASCO R. 2012. La Selección de Mercados Preferentes como Clave en la Internacionalización Empresarial. TEC Empresarial 1(6): 21-33.

CAHILL JP. 2004. Genetic diversity among varieties of Chia (Salvia hispanica L.). Genet Resour Crop Ev 51(7): 773-781.

CAMINO-MOGRO S, ANDRADE-DIAZ V \& PESANTEZ-VILLACIS D. 2016. Posicionamiento y eficiencia del banano, cacao y flores del Ecuador en el mercado mundial. Rev Cienc UNEMI 9(19): 48-53.

COLANTONE I \& SLEUWAEGEN L. 2010. International trade, exit and entry: a cross-country and industry analysis. J Int Bus Stud 41(7): 1240-1257.

COFACE - COMPAGNIE FRANÇAISE D'ASSURANCE POUR LE COMMERCE EXTÉRIEUR. 2017. Country risk assessment map, 2017. http://www. coface.com / News-Publications/Publications/ Country-risk-assessment-map-2nd-quarter-2017.

CUERVO-CAZURRA A. 2011. Selecting the country in which to start internationalization: The non-sequential internationalization model. J World Bus 46: 426-437.

EUROPEAN COMMISSION. 2016. Ecuador joins EU-Colombia/ Peru trade agreement. Available at: http://trade. ec.europa.eu/doclib/press/index.cfm?id=1576.

EUROPEAN FOOD SAFETY AUTHORITY. 2009. Opinion on the safety of 'Chia seeds (Salvia hispanica L.) and ground whole Chia seeds' as a food ingredient. Europ Food Saf Author J 996: 1-26.

GÓRECKA D \& SZAŁUCKA M. 2013. Country Market Selection in International Expansion Using Multicriteria Decision Aiding Methods. Mult Crit Decis Making 8: 31-55.

GRAND VIEW RESEARCH. 2016. Omega 3 Market Analysis By Application (Supplements and Functional Foods, Pharmaceuticals, Infant Formula, Pet and Animal Feed) And Segment Forecasts To 2022, Market Research Report Available at: https://www.grandviewresearch.com/ industry-analysis/omega-3-market.

HINGLEY M, LINDGREEN A \& CHEN L. 2009. Development of the grocery retail market in China: A qualitative study of how foreign and domestic retailers seek to increase market share. Brit Food J 111(1): 44-55.

HISRICH RD. 2015. Selecting International Business Opportunities. International Entrepreneurship: Starting, Developing, and Managing a Global Venture. Los Ángeles: SAGE Publications Inc.

PROECUADOR. 2017. Instituto de Promoción de Exportaciones e Inversiones. Evolución de las
Exportaciones No Petroleras por Sector. Available at: https://www.proecuador.gob.ec/wp-content/ uploads/2018/04/PROEC_EDE2017_JULIO.pdf.

MARCHI G, VIGNOLA M, FACCHINETTI G \& GIOVANN M. 2009. The decision process for the International Market Selection: A fuzzy model application to a small firm case. Eur J Marketing 48(11/12): 2198-2212.

MICHELLE LC \& BYOUNGHO J. 2014. Is Uppsala model valid to fashion retailers? An analysis from internationalization patterns of fast fashion retailers. Journal of Fashion Marketing and Management 18(1): 36-51.

MORTON C. 1995. The new Europe: an overview. Brit Food J 97(6): 6-13.

MUÑOZ LA, COBOS A, DÍAZ O \& AGUILERA JM. 2013. Chia Seed (Salvia hispanica): An Ancient Grain and a New Functional Food. Food Rev Int 29(4): 394-408.

NETHERLANDS MINISTRY OF FOREIGN AFFAIRS. 2016. Exporting chia seeds to Europe. Amsterdam: Netherlands Ministry of Foreign Affairs. Available at: https://www.cbi.eu/ market-information/oilseeds/chia-seeds/europe/.

RAMÍREZ-JARAMILLO G \& LOZANO-CONTRERAS MG. 2015. Potential for Growing Salvia hispanica L., Areas under Rainfed Conditions in Mexico. Agricult Sci 6(9): 1048-1057.

SAKARA S, ECKMAN M \& HYLLEGARD KH. 2007. Market Selection for International Expansion: Assessing Opportunities in Emerging Markets. Int Market Rev 24(2): 208-238.

SHENG SY \& MULLEN MR. 2011. A hybrid model for export market opportunity analysis. Int Market Rev 28(2): 163-182.

TERÁN-YÉPEZ EF \& SANTOS-ROLDÁN L. 2018. Toward international market selection: a practical tool to select the most appropriate export market. In: International Institute of Social and Economic Science Annual Conference, Seville. Proceedings of the IISES Annual Conference, Prague: International Institute of Social and Economic Sciences, p. 303-304.

U.S. FOOD AND DRUGS ASSOCIATION. 2013. Health Matters America Inc. Issues Nationwide Recall of Sprouted Flax Seed Powder and Sprouted Chia and Flax Seed Powder Because of Possible Health Risk. https://www.fda.gov/ safety/recalls/ucm487043.htm.

VIVIERS W, CUYVERS L, STEENKAMP E, GRATER S, MATTHEE M \& KRUGELL W. 2014. Identifying New Product and Service Export Opportunities for South Africa Using A Decision Support Model. International Business and Economics Research Journal 13(6): 1403-1417. 


\section{APPENDIX}

\section{EXPLANATORY GUIDE TO THE ELABORATION OF THE MARKET SELECTION TABLE (TABLE IX)}

1) The "criteria" field shows the 7 criteria (underlined in grey) as well as the 43 subcriteria chosen for target market selection.

2) The "datum" fields show the quantitative or qualitative values for every country for each corresponding subcriterion.

3) The "maximum value" field extracts the maximum value of the "datum" fields for each subcriterion.

4) The "base 10" fields are used in order to evaluate the importance of each datum on a unified scale from 0 to 10 (only whole numbers). A rule of 3 is used where the datum for each subcriterion of each country is multiplied by 10 and divided by the maximum value for each subcriterion. It must be mentioned that the "base 10 " fields are rounded up to whole numbers.

\section{Example:}

In the case of the subcriterion GDP 2016 for Spain, the base 10 formula would be as follows:

Datum of subcriterion for each country = GDP Spain 2016

Maximum value of or each subcriterion = maximum value of subcriterion GDP 2016

(GDP Spain $2016 \times 10$ ) / maximum value of subcriterion GDP $2016=$

$(1,113,851 \times 10) / 3,132,670=4$

This means that the country with the "maximum value" in each subcriterion receives a numerical value of 10 for this subcriterion, while the rest of the countries receive a proportional value depending on their value relative to the base 10 .
In the subcriteria where the "maximum value" represents the least adequate value, i.e. where lower values are more suitable (data underlined in yellow) like, for example, unemployment rate, as a lower unemployment rate is more favourable for a country than a higher one, the formula was inversed, meaning that the lowest value was assigned a 10 while the rest of countries received a proportional value relative to the base 10 , depending on their values.

1) The "weighting" field assigns a 1-3\% weighting to each subcriterion based on the studies presented in section 2.5. The sum of the subcriteria indicates the weighting assigned to each of the 7 criteria and thus defines the $100 \%$ scale.

2) Lastly, the "result" fields multiply the value for "base 10 " of each subcriterion for each country by the weighting for each subcriterion in order to obtain a percentage value for each subcriterion of each country.

\section{Example:}

Continuing the case of GDP 2016 for Spain, the formula would be as follows:

Base 10 value of each subcriterion for each country = base 10 value for subcriterion GDP 2016 Spain

Weighting of each subcriterion = weighting of subcriterion GDP 2016

Base 10 value for subcriterion GDP 2016 Spain $x$ weighting for subcriterion GDP $2016 x$ $10.00 \%=$

$4 \times 3.00 \% \times 10.00 \%=1.20 \%$

This is how the weighted value each country receives for each subcriterion is calculated. The sum of these percentages represents the value each country receives for each of the 7 criteria and, consequently the total percentage for each country on a scale with a maximum score of $100 \%$. 


\section{How to cite}

TERÁN-YÉPEZ E, SANTOS-ROLDÁN L, PALACIOS-FLORENCIO B \& BERBEL-PINEDA JM. 2020. Foreign market selection process as tool for international expansion: Case study for ecuadorian chia seeds exports to the european union. An Acad Bras Cienc 92: e20190513. DOI 10.1590/0001-3765202020190513.

Manuscript received on May 1, 2019; accepted

for publication on November 11, 2019

\section{EDUARDO TERÁN-YÉPEZ ${ }^{1}$}

https://orcid.org/0000-0002-1260-2477

\section{LUNA SANTOS-ROLDÁN ${ }^{2}$}

https://orcid.org/0000-0002-7429-9530

\section{BEATRIZ PALACIOS-FLORENCIO}

https://orcid.org/0000-0003-2789-7914

\section{JUAN MANUEL BERBEL-PINEDA ${ }^{3}$}

https://orcid.org/0000-0002-4783-9749

'University of Almeria, Department of Economics and Business, Calle San Urbano, s/n, 04120, La Cañada, Almeria, Spain

${ }^{2}$ University of Cordoba, Department of Business

Organization, Faculty of Business and Law, Puerta

Nueva Square, s/n, 14002, Cordoba, Spain

${ }^{3}$ University of Pablo de Olavide, Department of Business

Organization and Marketing, Faculty of Business

Studies, Carretera Utrera, Km.1, 41013, Seville.

Correspondence to Luna Santos-Roldán

E-mail: luna.santos@uco.es

\section{(cc) BY}

